\title{
Topoisomerase I Inhibitor Genz-644282
}

National Cancer Institute

\section{Source}

National Cancer Institute. Topoisomerase I Inhibitor Genz-644282. NCI Thesaurus. Code C84851.

A non-camptothecin inhibitor of topoisomerase I with potential antineoplastic activity.

Topoisomerase I inhibitor Genz-644282 binds to and inhibits the enzyme topoisomerase I, which may result in the inhibition of repair of sing le-strand DNA breaks, DNA replication, and tumor cell growth in susceptible tumor cell populations. 